\title{
Novel extraction of high quality genomic DNA from frozen bovine blood samples by using detergent method
}

\author{
Talla Sridhar Goud ${ }^{1,2}$, Ramesh Chandra Upadhyay ${ }^{1}$, Anil Kumar ${ }^{1}$, Satyanagalakshmi Karri², Renuka Choudhary ${ }^{1}$, \\ Syma Ashraf ${ }^{1}$, Sohan Vir Singh ${ }^{1}$, Onteru Suneel Kumar ${ }^{3}$ and Chadipiralla Kiranmai ${ }^{2, *}$ \\ ${ }^{\text {I} C l i m a t e ~ R e s i l i e n t ~ L i v e ~ S t o c k ~ R e s e a r c h ~ C e n t r e, ~ I C A R-N a t i o n a l ~ D a i r y ~ R e s e a r c h ~ I n s t i t u t e, ~ K a r n a l-132001, ~ H a r y a n a, ~}$ \\ India \\ ${ }^{2}$ Department of Biotechnology, Vikrama Simhapuri University, Nellore-524003 Andhrapradesh, India \\ ${ }^{3}$ Molecular Endocrinology and Structural Biology, Animal Biochemistry Division, ICAR-National Dairy Research \\ Institute, Karnal-132001, Haryana, India
}

\begin{abstract}
DNA is the prerequisite for life's inception that transfers hereditary information, past several years; various types of commercial kits are made available which vary depending on the type of the biological sample being used. The present study is focused on developing an improvised methodology for the isolation of genomic DNA from stored bovine blood samples. DNA was isolated by using the conventional Phenol: Chloroform: Isoamyl alcohol (PCI) method and Detergent method. The aim of the study was to make a comparative analysis and evaluation of these two methods to identify the one that gives a superior quality and quantity of genomic DNA. Total $(n=48)$ each duplicate blood samples from three different buffalo(Bubalus bubalis) breeds Banni, Surti, Murrah, three zebu cattle (Bos indicus) breeds Kankerj, Gir, Sahiwal were collected from the jugular vein. The quantity, purity of the genomic DNA was assessed based on the total DNA yield, purity ratios, spectral profile, agarose gel electrophoresis analysis and polymerase chain reaction amplification of MC1R gene product without any inhibitors. The results of our study suggest that detergent method is also suitable for extraction of genomic DNA from the bovine blood and results were significant $(* P>0.05)$. The total mean yield was found to be $329.05 \pm 11 \mu \mathrm{g} / 5 \mathrm{ml}$ for all six breeds while the PCI method was employed. The total mean yield of the gDNA for all six breeds was $406.6 \pm 43 \mu \mathrm{g} / 5 \mathrm{ml}$ of blood when the detergent method was used. One way ANOVA test showed that the total DNA yield varied depending on the isolation method used. The DNA yield obtained from the DG method was $(* * * P<0.001)$ significant as compared to the PCI method $(* * P<0.01)$.

Keywords: DG method, gDNA, Melanocortin-1-receptor gene, PCI method, Total lymphocytes.
\end{abstract}

\section{Introduction}

In current modern era growth of molecular biology, animal biotechnology, veterinary and agricultural science large practical applications of their achievement have been observed. Genomic research area benefits for the large genomic population studies for human, animal, plant and other mammalian species. The ruminant livestock in sustainable agricultural systems plays a major significant role (Hackmann and Spain, 2010). Genomic DNA considers as a major important molecule in genetic testing (Bakker, 2006). Isolation of genomic DNA is a most important step in a variety of clinically related studies including genetics, genomics, gene polymorphism, DNA fingerprinting and gene sequencing. These studies exploit a number of techniques to facilitate which include, restriction fragment length polymorphism (RFLP), real-time polymerase chain reaction (RT-PCR), Sangersequencing and microarrays and Next-generation sequencing (Bakker, 2006). Whole blood is one of the accessible sources to obtain the genomic DNA.
Consistency, possibility, and reproducibility of molecular inheritance studies are often limited by the primary step of the DNA isolation. To obtain a large amount of genomic DNA from cells and tissue is often a laborious task. DNA isolation methods should be ideally is efficient, reliable, quick and reproducible. Whole blood is a vital resource for the isolation of genomic DNA from bovine and yak (Neary et al., 2014).

In molecular biology studies, which includes the breed recognition, food nutritional functions and food traceability, genetic difference along with animals, marker-assisted studies of breeding, in genetic hybridization studies requires high-quality genomic DNA for southern blotting test (Murphy et al., 2002). The source of genomic DNA from bovine mainly blood and other tissue parts which require professional people and it was a laborious process to get the samples.

In the present research, various techniques available to isolate the genomic DNA from blood and also other biological materials like nails, meat, semen, and hair 
follicles are described (Suenaga and Nakamura, 2005; Green and Sambrook, 2012; Griffin, 2013).

Blood is the most common tissue use to isolate the DNA, therefore many methods, available to isolate DNA from different body fluids, and tissues, a new method for isolation to allow for the high amount of quantity, and purity of genomic DNA. This is most significant in livestock genetic research, sufficient amount of DNA was obtained from the whole blood samples and several reports were already made (Chacon-Cortes et al., 2012; Ghaheri et al., 2016) which includes regular organic method Phenol: Chloroform: Isoamyl alcohol (Di Pietro et al., 2011).

On the other hand, the toxic nature of phenol and chloroform it remains a most important concern while it is used for DNA extraction caution should be taken wearing the gloves and nose musk.

The current method we applied regular Phenol: Chloroform: Isoamyl alcohol and different types of detergents method utilize. It is regularly utilized for extraction of genomic DNA from whole blood samples and also used diverse types of biological samples (Goldenberger et al., 1995; Hassani and Khan, 2015; Murray et al., 2016; Qamar et al., 2017).

\section{Chemicals and plastic ware}

\section{Materials and Methods}

All chemicals were purchased from Molecular grade Sigma Chemical Co. (St. Louis, MO, USA). Oligonucleotide primers were synthesized by (Sigma, India) Ready Mix ${ }^{\mathrm{TM}} \mathrm{Taq}$ PCR mix with $\mathrm{MgCl}_{2}$ (Cat No. P4600) (St. Louis, MO, USA) unless otherwise indicated. $15 \mathrm{ml}$ falcon tubes (Nunc Thermo Scientific, USA), $1.5 \mathrm{ml}$ Eppendorf tubes (Axygen, CA, USA) vacutainer (Cat.No.K2E ${ }^{\circledR} \mathrm{REF}$ 367525) tubes were purchased (BD Biosciences, UK).

\section{Experimental design and Blood Sample collection}

Total $(n=48)$ each animal duplicate samples of each breed Banni, Surti buffalo (Bubalus bubalis), Gir and Kankrej (Bos indicus) cattle were selected for the study from Dantiwada Agricultural University and Navsari Agricultural University (Gujarat). Whereas Murrah buffalo and Sahiwal cattle (1 to 2 year) healthy heifers were selected from ICAR-National Dairy Research Institute, Karnal (Haryana) Live Stock Research Centre managed under open housing system.

Animals were clinically healthy and free from any physical abnormalities. All animals were closely monitored during the period of study. The blood sample was drawn from the punctured jugular vein with the help of 18 gauge needle in the $5 \pm 1 \mathrm{ml}$ of the blood sample in $\mathrm{K} 2$ EDTA from $\mathrm{BD}$ vacutainer tubes $(1 \mathrm{mg} / \mathrm{ml})$. Blood samples were stored at $-20^{\circ} \mathrm{C}$ freezers for 2 to 4 years.

\section{Ethical Permission}

All the experimental procedures were approved Institutional Animal Ethics Committee (IAEC) by at the ICAR- National Dairy Research Institute (NDRI), Karnal and constituted as per article number 13 of the CPCSEA rules followed by Government of India.

\section{Genomic DNA isolation methods}

Modified Phenol: Chloroform: Isoamyl alcohol method

For isolating the DNA using a traditional PCI method, clotted samples were thawed to liquefy the blood samples. Concisely the isolation procedures for the blood sample was performed as described below. The peripheral blood sample $(5 \mathrm{ml})$ was collected in $\mathrm{K} 2$ EDTA-vacutainer and the whole blood was transferred into a $15 \mathrm{ml}$ falcon tube and centrifuged for $20 \mathrm{~min}$ at $3500 \mathrm{rpm}$ to separate buffy coat. The separated buffy coat was then transferred to a15ml falcon tube into which $1.5 \mathrm{ml}$ of RBC lysis buffer (Sucrose-1M Tris$\mathrm{HCl}$ (Sigma, USA) pH-8, $1 \mathrm{M} \mathrm{MgCl}_{2}$ (Sigma, USA), Triton X-100 (Sigma, USA) were added. Chilled double distilled water $(3 \mathrm{ml})$ was added to this mixture and centrifuged at $3500 \mathrm{rpm}$ for 12 minutes. The pellet was collected and suspended in equal volumes of RBC lysis buffer and chilled distilled water. The pellet was made uniform and then centrifuged again at $3500 \mathrm{rpm}$ for $12 \mathrm{~min}$. This step was repeated until a clear WBC pellet was obtained following which $1 \mathrm{ml}$ of WBC lysis buffer (1M Tris- $\mathrm{HCl}$ (pH-8), 0.5M Na2-EDTA (Sigma, USA) was added. To this mixture, $1 \mathrm{M} \mathrm{NaCl}_{2}$ was added along with $250 \mu \mathrm{l}$ of $20 \%$ detergent SDS (Sigma, USA) and proteinase-K $(20 \mathrm{mg} / \mu \mathrm{l})$ (Sigma, USA) and incubated for $10 \mathrm{hrs}$ at $37^{\circ} \mathrm{C}$.

Following incubation, $200 \mu 15 \mathrm{M} \mathrm{NaCl}_{2}$ was added and Centrifuged at $10000 \mathrm{rpm}$ for $10 \mathrm{~min}$ at $4^{\circ} \mathrm{C}$. The supernatant was mixed with an equal volume of PCI (25:24:1). The tubes were well mixed and centrifuged at $8000 \mathrm{rpm}$ for $5 \mathrm{~min}$ at $4^{\circ} \mathrm{C}$. The supernatant was transferred into a centrifuge tube and equal volume of Chloroform: Isoamyl alcohol (24:1) was added and centrifuged it at $8000 \mathrm{rpm}$ for $5 \mathrm{~min}$ at $4^{\circ} \mathrm{C}$. DNA was precipitated by the addition of $200 \mu \mathrm{l}$ of chilled $3.5 \mathrm{M}$ sodium acetate ( $\mathrm{pH}$ 5.2) (Sigma, USA) and $-20^{\circ} \mathrm{C}$ chilled absolute (100\%) alcohol to the obtained supernatant. The precipitate was washed with chilled $70 \%$ alcohol twice to remove contaminants. The DNA was precipitated and transferred into $1.5 \mathrm{ml}$ fresh tube and air dried the pellet at $55^{\circ} \mathrm{C}$ for $10 \mathrm{~min}$. Genomic DNA precipitant was re-suspended in $150 \mu \mathrm{l}$ of $\mathrm{TE}$ buffer (10 mM Tris-HCl, $1 \mathrm{mM}$ EDTA pH-8). Samples were labeled and stored in $-20^{\circ} \mathrm{C}$ freezer for further molecular studies.

\section{Genomic DNA Isolation by using Detergent (DG) method}

The whole blood was centrifuged at $3500 \mathrm{rpm}$ for 15 min and separated the buffy coat that was transferred into a $15 \mathrm{ml}$ centrifuge tube and to this $1.5 \mathrm{ml}$ of RBC lysis buffer (Sucrose-1M Tris-HCl (Sigma, USA) pH8, $1 \mathrm{M} \mathrm{MgCl}_{2}$ (Sigma, USA) and Triton X-100 (Sigma, 
USA) was added. To this, $3 \mathrm{ml}$ of chilled double distilled water was added and centrifuged at $3500 \mathrm{rpm}$ for 12 minutes. The pellet was collected; an equal volume of RBC lysis and chilled distilled water were added. The pellet was made uniform and then centrifuged again at $3500 \mathrm{rpm}$ for $12 \mathrm{~min}$. This step was repeated to get a clear WBC pellet. Later, $1 \mathrm{ml} \mathrm{WBC}$ lysis buffer (1M Tris-HCl (pH-8), 0.5M Na 2 -EDTA (Sigma, USA), and $1 \mathrm{M} \mathrm{NaCl}_{2}$ ) was added along with $250 \mu \mathrm{l}$ of $2 \%$ detergent which was dissolved in nuclease-free water instead of (SDS \& proteinase-K). In the current study, we used various commercial laundry detergent powders available in (India) (Ariel $(\mathrm{P} \& \mathrm{G})$, Tide $(\mathrm{P} \& \mathrm{G})$, Sardar, Fena, Rin (Hindustan lever Itd India) and Surf excel (Hindustan lever 1td India) and incubated for $1 \mathrm{hr}$ at $37^{\circ} \mathrm{C}$.

After incubation, $200 \mu \mathrm{l}$ of $5 \mathrm{M} \mathrm{NaCl}_{2}$ was added and Centrifuged at $10000 \mathrm{rpm}$ for $10 \mathrm{~min}$ at $4^{\circ} \mathrm{C}$. The supernatant was mixed with an equal volume of PCI (25:24:1). Vortex the tubes and centrifuged it at 8000 $\mathrm{rpm}$ for $5 \mathrm{~min}$ at $4^{\circ} \mathrm{C}$. The supernatant was transferred into a centrifuge tube and equal volume of Chloroform: Iso-amyl alcohol (24:1) was added and centrifuged it at $8000 \mathrm{rpm}$ for $5 \mathrm{~min}$ at $4^{\circ} \mathrm{C}$. DNA was precipitated by the addition of $200 \mu \mathrm{l}$ of chilled $3.5 \mathrm{M}$ sodium acetate (pH 5.2) and $-20^{\circ} \mathrm{C}$ chilled absolute (100\%) alcohol to the obtained supernatant and was thoroughly mixed. The precipitate was washed twice with $70 \%$ alcohol to remove contaminants. Precipitated DNA pellet was dried at $55^{\circ} \mathrm{C}$ for $10 \mathrm{~min}$ and re-suspended in $150 \mu \mathrm{l}$ of TE buffer (10 mM Tris-HCl, 1mM EDTA pH-8) and stored in $-20^{\circ} \mathrm{C}$ till further use.

Quality and quantity measurement of extracted gDNA The quality and quantity of the gDNA extracted by PCI and Detergent methods were assessed by using a NanoDrop Spectrophotometer (Shimadzu BioSpec-nano® Japan). The ratio of absorbance was measured at 260 $\mathrm{nm}$ and $280 \mathrm{~nm}$ to determine the protein contamination phenol or guanidium salts, aromatic compounds, peptides, and carbohydrates.

Good concentration of gDNA was associated with better gDNA quantity and purity. Genomic DNA with 260/280 nm ratio between 1.80-1.90 was considered pure. The PCI and DG samples were blanked by using TE buffer.

\section{Gel Electrophoresis}

To evaluate the probability of DNA integrity, quality of DNA isolated was assessed by agarose gel electrophoresis. $2 \mu \mathrm{l}(100 \mathrm{ng} / \mu \mathrm{l})$ of extracted gDNA along with bromophenol blue dye (Sigma, USA) was loaded on $0.8 \%$ agarose gel and subjected to electrophoresis (Genetixs Biotech, Asia). The bands were visualized by UV-trans illumination gel documentation system (Bio-Rad XR Imager, USA). The gDNA integrity was assessed by using Bio-Rad Gel Pro software.

\section{Restriction Enzyme Digestion}

Approximately $1 \mu \mathrm{g}$ of genomic DNA was digested with EcoRI, SauIII fast digestion enzymes by (Thermo Scientific, USA) incubating the samples at $37^{\circ} \mathrm{C}$ for 5 minutes. Following incubation, the digested samples and undigested controls were electrophoresed on $1.2 \%$ agarose gel. DNA ladder (1kb) (Sigma, USA) was run as a standard, parallelly in one of the wells. The separated bands were visualized by ethidium bromide staining and analyzed under a gel documentation system.

\section{Gene amplification}

PCR amplification protocols were performed using the isolated gDNA from a blood sample of bovine. The Primers was designed using bovine gene bank accession numbers (NM_174108.2) by using primer-3 Software.

Forward Primer: 5'-

GGACCCTGAGAGAGCAAGCAC-3'

Reverse Primer: 5'-

CTCACCTTCAGGGATGGTCTA-3'.

PCR reaction was performed to confirm the intactness of the genomic DNA and to determine whether any inhibitory material was interfering with the reaction. For this purpose, a fragment of MC1R gene was amplified in a $25 \mu \mathrm{l}$ volume, consist of $12.5 \mu \mathrm{l}$ PCR Master mix ready to use Kit (1x) (Sigma, USA), and the primer stock solution was prepared by $100 \mu \mathrm{M} / \mu \mathrm{l}$ concentration.

The working solution was diluted into 10 pico-moles/ $\mu 1$ concentration of MC1R gene primers. The PCR protocol conditions were: $95^{\circ} \mathrm{C}$ for $3 \mathrm{~min} ; 35$ cycles at $94^{\circ} \mathrm{C}$ for $1 \mathrm{~min} ; 59^{\circ} \mathrm{C}$ for min and $72^{\circ} \mathrm{C}$ for $1 \mathrm{~min}$; and $72^{\circ} \mathrm{C}$ for $10 \mathrm{~min}$. For each sample, (Applied BioSystem Gene Amp ® PCR 9700 USA) $5 \mu 1$ of PCR products were separated on $1.4 \%$ agarose gel, along with $1 \mathrm{~kb}$ molecular ladder (Sigma, USA) and the bands were visualized by UV-trans illumination gel documentation system (Bio-Rad, USA) after staining with ethidium bromide $(0.5 \mu \mathrm{g} / \mathrm{ml}$ concentration $)$.

To confirm the PCR products following clean up with the kit (Thermo Scientific, India) the DNA samples were sequenced and analyzed using the ABI PRISM 3730 Genetic Analyser (Applied BioSystems). The sequence was queried for sequence similarity using the BLAST tool (http://blast.ncbi.nlm.nih.gov/Blast.cgi), against known sequences in the NCBI database and was found to have a $100 \%$ identity to MC1R gene of bovine sequences were submitted to National Centre for Biotechnology Information gene bank acc.id. For buffalo breeds KM023144, KM023142, KP031113 and cattle breeds KR363036, KM103645, and KM103647.

\section{Statistical analysis}

The data were analyzed using the GraphPad Prism (version 5.01). Experimental results were presented as Mean \pm SEM (Standard Error Mean). Data were 
subjected to analysis of variance (One-way ANOVA), followed by Dunnett's multiple comparative tests. A Pvalue $<0.05$ was considered statistically significant.

\section{Results}

A Total of 48 samples were used for extraction of the genomic DNA. $5 \mathrm{ml}$ of blood samples were drawn from each breed of the buffalo and cattle. Samples were used for extracting the gDNA employing two methods; traditional PCI and detergent methods. Table 1 shows the various breeds and the detergents were used for isolation of the genomic DNA.

The mean DNA yields obtained employing PCI method for various breeds were Banni (2312.86 $\pm 179 * *)$, Surti $(2090.92 \pm 267 * *)$, Murrah $\left(2039.18 \pm 495^{* *}\right)$, Kankrej $(2213.28 \pm 102 * *)$, Gir $(2500.48 \pm 134 * *)$ and Sahiwal $(2010.96 \pm 124 * *) \mathrm{ng} / \mu \mathrm{l}$. Similarly, the mean DNA yields obtained using the detergent method in various breeds were Banni $(3857.92 \pm 189 * *)$, Surti $\left(2207.92 \pm 366^{* * *}\right)$, Murrah (2144.94 $\left.\pm 256 * *\right)$, Kankrej $(3028.28 \pm 387 * * *), \operatorname{Gir}(2995.21 \pm 370 * * *)$ and Sahiwal

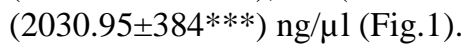

Our results indicate that the DNA extracted through the detergent method was significantly more yield as compared to the traditional PCI method. The total yield of the extracted gDNA of each of the samples was calculated by multiplying the DNA concentration with the final elution volume of $150 \mu$ l. Figure 2 represents the mean total yield of DNA isolated using the two different methods. The mean yield was found to be $329.05 \pm 11 \mu \mathrm{g} / 5 \mathrm{ml}$ for all six breeds while the PCI method was employed. On the other hand, the total mean yield of the isolated DNA for all six breeds was $406.6 \pm 43 \mu \mathrm{g}$ per $5 \mathrm{ml}$ from whole blood when the detergent method was used (Fig.2).

Comparison of mean ranks using the ANOVA test showed that the total DNA yield varied depending on the isolation method used $(* * P<0.01$, $* * * P<0.001)$. The DNA yield obtained from the DG method was significantly higher compared to the PCI method $(* P<0.05)$. Table 1 shows the comparison of DNA yields from $5 \mathrm{ml}$ blood samples taken from all 48 animals, among the two extraction methods. The apparent higher difference in the standard error of DNA yield for the DG method than the PCI method was due to the higher mean value of DNA yield when using the DG method as compared to PCI. In bovine we found that the mean total highest yield was obtained from 5 $\mathrm{ml}$ of whole blood frozen samples was reported the first time.

To assess the purity of the DNA extracted by the two different methods, absorbance was measured at 260 and $280 \mathrm{~nm}$ wavelengths, and the ratio of these absorbance was computed to estimate the relative purity of the test samples. A260/A280 ratios were summarized in Table 1. The DG method extracted the purest DNA from the 48 samples with a mean A260/A280 ratio of $1.9 \pm 0.02$ and the PCI method also got the similar mean $1.86 \pm 0.02$ (Fig.3). The differences in the means of these two methods of DNA isolation was not statistically significant $(\mathrm{P}>0.05)$. Pure gDNA has an OD 260/280 values ranging from of 1.8 and 2.0 and is considered as good purity (Huberman, 1995; Chen et al., 2010). It was observed that the nanodrop spectrophotometric measurements for DNA quality evaluation with higher values related to improved DNA purity (Psifidi et al., 2015).

Once the gDNA evaluations were done by using spectroscopy shown (Fig.4) and agarose gel electrophoresis shown in (Fig.5a) the gDNA was further analyzed by polymerase chain reaction using the bovine-specific Melanocortin 1 receptor candidate gene for coat color. The gene was majorly responsible for the synthesis of melanin pigments (eumelanin and pheomelanin) in bovine coat color. We tested the genomic DNA isolated by traditional PCI method and detergent method as a template for further PCR analysis, and the DNA banding pattern is shown in (Fig.5b). There was no inhibitor present in the PCR and Restriction digestion by using PCI and Detergents methods. Further, the gDNA was tested by restriction enzyme digestion using E.CoRI and SauIII and the bands were shown clearly in $1.2 \%$ agarose gel electrophoresis (data was not shown). Genomic DNA isolated through both PCI and detergent methods were quite suitable for performing the above experiments and hence are further suitable genomic applications. While analyzing the cost-effectiveness of the methods, we compared both the methods based on the prices availability of the local providers. The data are shown in Table 2. In the aspects of time, we compared both traditional PCI and DG methods. Traditional PCI method has a more lengthy protocol and also involves the gDNA samples in a $37^{\circ} \mathrm{C}$ incubator and overnight digestion with the proteinase-K. The cost of the PCI method per sample was almost double the amount compared to the detergent method. Hence the detergent method is a cost-effective and time-saving procedure.

\section{Analysis of time cost and labor intensity}

Comparison of two extraction methods for labor intensity, throughout time and material cost per sample was reported in results. PCI was the most laborious process to keep the blood sample for RBC lysis for overnight incubation at $37^{\circ} \mathrm{C}$ with proteinase-K. The $\mathrm{PCI}$ protocol was the most precisely difficult to perform and also required the use of highly toxic phenol while performing the experiment caution should be taken with PCI wearing the gloves and nose mask. Relatively, the detergent method was the cheapest since it did not require the use of enzymes, whereas, the silica columnbased method was the most expensive per sample. Our method was yielded the highest quantity and quality of gDNA from frozen bovine blood samples. 
Table 1. Genomic DNA extracted by PCI method and Detergent method.

\begin{tabular}{|c|c|c|c|c|c|c|c|c|c|}
\hline NO. & $\begin{array}{l}\text { Breed } \\
\text { Name }\end{array}$ & $\begin{array}{l}\text { Coat } \\
\text { colour }\end{array}$ & $\begin{array}{c}\text { PCI Method } \\
(\text { mean } \pm \text { SE) } \\
\text { ng/ } / \mu 1\end{array}$ & $\begin{array}{c}\text { Purity } \\
260 / 280 \mathrm{~nm} \\
\text { (PCI) }\end{array}$ & $\begin{array}{c}\text { Total gDNA } \\
\text { yield in } \\
\mu \mathrm{g} / 5 \mathrm{ml} \\
\end{array}$ & $\begin{array}{c}\text { Detergent } \\
\text { Name }\end{array}$ & $\begin{array}{c}\text { Detergent Method } \\
(\text { mean } \pm \text { SE }) \\
\mathrm{ng} / \mu \mathrm{l}\end{array}$ & $\begin{array}{c}\text { Purity } \\
260 / 280 \mathrm{~nm} \\
\text { (DG) }\end{array}$ & $\begin{array}{c}\text { Total gDNA } \\
\text { yield in } \\
\mu \mathrm{g} / 5 \mathrm{ml}\end{array}$ \\
\hline 1 & Banni & Black & $2312.86 \pm 179$ & $1.96 \pm 0.00$ & $346.92 \pm 26^{* *}$ & $\begin{array}{l}\text { Ariel } \\
\text { (DG1) }\end{array}$ & $3857.92 \pm 189$ & $1.82 \pm 0.08$ & $578.68 \pm 28^{* *}$ \\
\hline 2 & Surti & Brown & $2090.92 \pm 267$ & $1.82 \pm 0.01$ & $313.63 \pm 40^{* *}$ & $\begin{array}{l}\text { Fena } \\
\text { (DG2) }\end{array}$ & $2207.92 \pm 366$ & $1.93 \pm 0.02$ & $331.18 \pm 54^{* * *}$ \\
\hline 3 & Murrah & Jet Black & $2039.18 \pm 495$ & $1.85 \pm 0.03$ & $305.87 \pm 74^{* *}$ & $\begin{array}{c}\text { Rin } \\
\text { (DG3) }\end{array}$ & $2144.94 \pm 256$ & $1.85 \pm 0.06$ & $321.74 \pm 57^{* * *}$ \\
\hline 4 & Kankrej & $\begin{array}{l}\text { Silver } \\
\text { Gray }\end{array}$ & $2213.28 \pm 102$ & $1.81 \pm 0.01$ & $331.19 \pm 15^{* *}$ & $\begin{array}{l}\text { Tide } \\
\text { (DG4) }\end{array}$ & $3028.28 \pm 387$ & $1.95 \pm 0.02$ & $454.24 \pm 58^{* * *}$ \\
\hline 5 & Gir & $\begin{array}{l}\text { Red } \\
\text { Yellow }\end{array}$ & $2500.48 \pm 134$ & $1.81 \pm 0.01$ & $375.07 \pm 20^{* *}$ & $\begin{array}{l}\text { Sardar } \\
\text { (DG5) }\end{array}$ & $2995.21 \pm 370$ & $1.95 \pm 0.01$ & $449.28 \pm 55^{* * *}$ \\
\hline 6 & Sahiwal & $\begin{array}{c}\text { Red } \\
\text { Brown }\end{array}$ & $2010.96 \pm 124$ & $1.91 \pm 0.01$ & $301.64 \pm 18^{* *}$ & $\begin{array}{c}\text { Surfexcel } \\
\text { (DG6) }\end{array}$ & $2030.95 \pm 384$ & $1.90 \pm 0.02$ & $304.64 \pm 57^{* * * *}$ \\
\hline \multicolumn{3}{|c|}{ Mean \pm SE } & $2194.61 \pm 76$ & $1.86 \pm 0.02$ & $329.05 \pm 11$ & & $2710.87 \pm 290$ & $1.90 \pm 0.02$ & $406.6 \pm 43^{*}$ \\
\hline
\end{tabular}

Each breed consists of eight animals (48 in total). Asterisk mark indicates significant difference $\left({ }^{* * *} P>0.001 ;{ }^{* *} P>0.01 ;{ }^{*} P>0.05\right)$.

Table 2. Cost of the DNA extraction per sample, total number of samples and time duration for all samples of the PCI method and Detergent method.

\begin{tabular}{ccccccc}
\hline No. & $\begin{array}{c}\text { Extraction } \\
\text { Method }\end{array}$ & $\begin{array}{c}\text { Blood volume } \\
\text { in }(\mathrm{ml})\end{array}$ & $\begin{array}{c}\text { Elution volume } \\
\text { in }(\mu \mathrm{l})\end{array}$ & $\begin{array}{c}\text { Duration of Time } \\
\text { total 48) samples }\end{array}$ & Cost Per Sample Rs $(\$)$ & $\begin{array}{c}\text { Cost Per Total } \\
\text { Samples Rs }(\$)\end{array}$ \\
\hline 1 & PCI & 5 & 150 & $12-16 \mathrm{hrs}$ & $4.52(0.07)$ & $217.16(3.25)$ \\
2 & Detergent & 5 & 150 & $1-2 \mathrm{hrs}$ & $1.24(0.02)$ & $59.6(0.89)$ \\
\hline
\end{tabular}

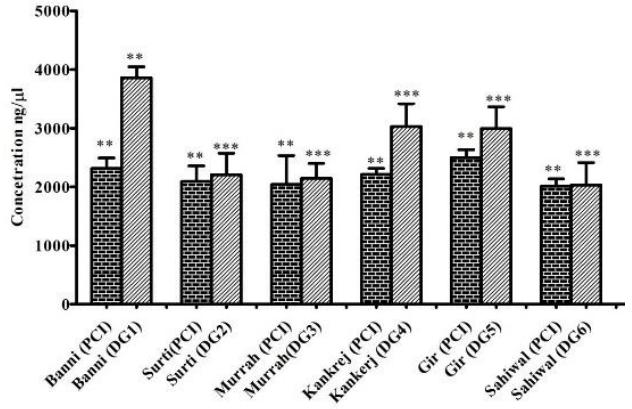

Fig.1 Graph indicates the three individual buffalo breeds and three individual cattle breeds genomic DNA concentration (ng/ $\mu 1)$ by using PCI and Detergent method. (DG1): Ariel; (DG2): Fena; (DG3): Rin; (DG4): Tide; (DG5): Sardar; (DG6): Surf-excel. Asterisk mark indicates the significant difference $\left({ }^{* *} P>0.01 ;{ }^{* * *} P>0.001\right)$.

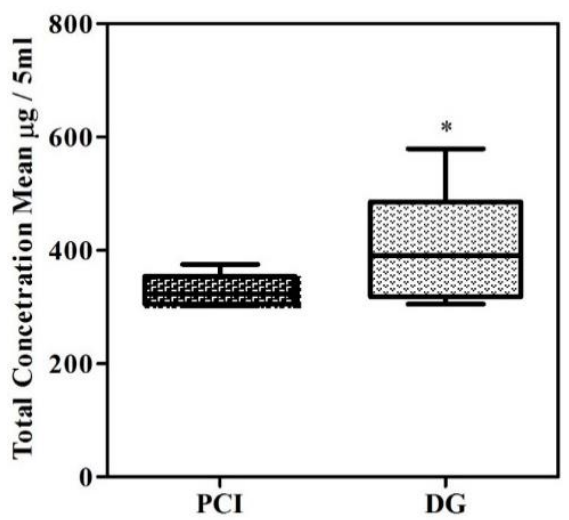

Fig.2. Represents all the six breeds total mean genomic DNA concentration $(\mu \mathrm{g} / 5 \mathrm{ml})$ by using PCI and Detergents method. Asterisk indicates the significant difference $\left({ }^{*} P>0.05\right)$.

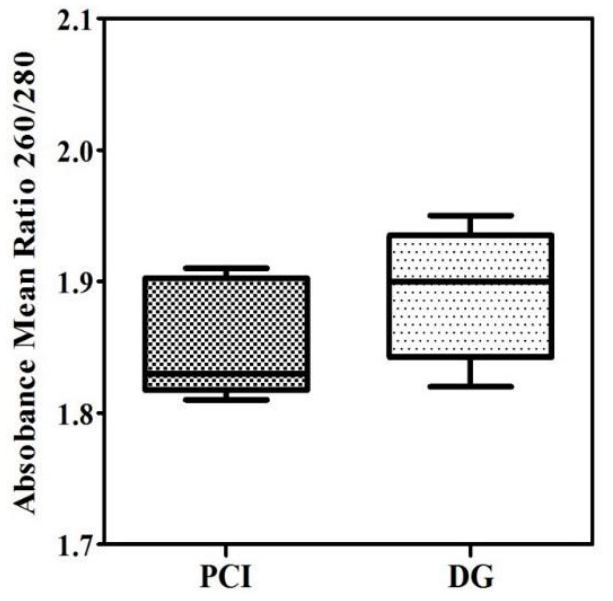

Fig. 3. Total mean genomic DNA purity Ratio absorbance at 260/280 $\mathrm{nm}$ by using PCI and Detergents method.
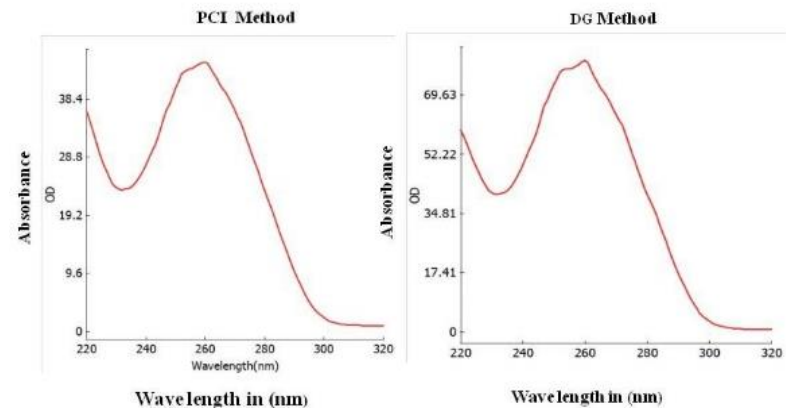

Fig. 4. Spectral profile indicates the genomic DNA extraction from bovine whole blood samples by using PCI and DG methods. Spectrum peaks wavelength was measured at 220 to $320 \mathrm{~nm}$ by using nano-drop spectrophotometer. 


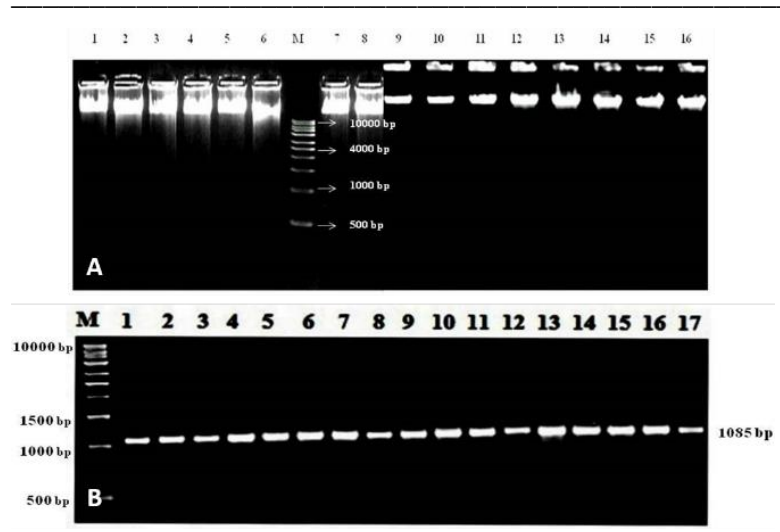

Fig. 5. Agarose gel electrophoresis. (A): Genomic DNA bands by PCI method (1-8 lanes) and detergent method (9-16 lanes). (B): PCR product of the PCI method (1-9 lanes) and detergent method (10-17 lanes). (M): Marker 1kb.

\section{Discussion}

Genomic DNA is an important component in order to perform molecular applications involving genomic studies (Lundblom et al., 2011; Chacon-Cortes et al., 2012). Blood clots are a valuable source of animal and human genomic DNA. Current efforts in molecular medicine and genetic epidemiology progressively consider about partnerships with accessible bio-banks of gDNA containing samples because of the study base. In this respect, the recovery and amplification of nucleic acids from different sources of biological samples (e.g. archived formalin-fixed autopsy tissues, dried blood spots, frozen serum and plasma, LTS whole blood) are becoming increasingly important in genetic studies. Further, whole genome sequencing, large-scale applications like SNP genotyping and NGS technology are being heavily used in modern sciences (Psifidi et al., 2015). Isolation of gDNA from blood was herculean task to puncture the jugular vein of the large animals like cattle and buffalo and other livestock species goat, sheep (Joshi et al., 1998; Jiri and Petrek, 2002; Kumar et al., 2006; Psifidi et al., 2010, 2015; Koshy et al., 2016). The present study was the comparison between the detergent method and the PCI method. By using our method we got significantly higher quantity, quality and intact gDNA from 2-4 years old blood samples which are stored at $-20^{\circ} \mathrm{C}$. Successful DNA isolation would be one that could extract the high yield consistently across the samples from a large number of individuals with high quantity, purity and the less time period. Different kinds of methods are available for gDNA extraction based on chemical and mechanical lysis of cells (Devi et al., 2015). There are an ambiguity and problems in choosing the best methods that not only are able to recover a high amount of nucleic acids but also give a higher yield of amplifiable copies.

In this current study, we have made a careful comparison between two methods of gDNA extraction from the blood samples of three different breeds of buffalos and cattle.

Current genomic applications like genomic library preparation, cloning, and sequencing require a high amount of intact genomic DNA used by the PCI method preferably. Few studies have mentioned EDTA vacationers to be the best to store the whole blood samples for long storage in frozen condition (Permenter et al., 2015). The study by Neary et al. (2014) reported a lesser amount of yield in the blood sample (11.7 \pm 0.7$)$ $\mathrm{ng} / \mu \mathrm{l}$ as compared to that of the saliva swabs $(574 \pm 28.9) \mathrm{ng} / \mu \mathrm{l}$ in European cattle breed (Neary et al., 2014). Some of the authors mentioned using the different kinds of detergents from various manufacturers (Airel, Active wheel, Tide, Henko stain Champion, Rin, and Ezee) to get the better yield of the genomic DNA from goat blood samples (Kumar et al., 2006). Earlier studies with detergents in bovine samples reported a significantly lesser yield of 3-5 $\mu \mathrm{g}$ DNA in freshly collected blood samples (Bailes et al., 2007). Our results showed that by using the PCI method we got the respective mean values $346.92 \pm 26$, $313.63 \pm 40,305.87 \pm 74,331.19 \pm 15,375.07 \pm 20$ and $301.64 \pm 18 \mu \mathrm{g} / 5 \mathrm{ml}$ of the blood sample. By using different detergents (Ariel, Fena, Rin, Tide, Sardar, and Surf excel) individual breed respective mean values were $578.68 \pm 28,331.18 \pm 54,321.74 \pm 57,454.24 \pm 58$, $449.28 \pm 55$ and $304.64 \pm 57 \mu \mathrm{g}$ per $5 \mathrm{ml}$ of frozen blood samples of bovine.

Different concentrations of detergents were used to extract genomic DNA is useful, whereas depending upon the amount of dilution and brands type, purity of the DNA varies, which should be noted during DNA extraction (Nasiri et al., 2005; Kumar et al., 2006). Studies that were already reported had no influence on purity and integrity of DNA during extraction by using the different type of laundry detergent powder brands and no significant difference between results was observed (Nasiri et al., 2005). In Holstein Friesian cattle and Soay sheep by using non-silica membrane kit based method total yield of DNA was obtained by $76 \pm$ $2 \mu \mathrm{g}$ and $74 \pm 1 \mu \mathrm{g}$ of the blood sample (Seeker et al., 2016). DNA extracted from milk samples resulted in total gDNA concentration range between 12 to $45 \mu \mathrm{g} / \mu \mathrm{l}$ in Chinese Holstein cows (Liu et al., 2014). Recent studies have reported that the results obtained could vary to different degrees and is dependent on the kind of biological sample being used viz. mammalian species like human, goat, sheep, and cow (Al-Shuhaib, 2017). Based on the current results, our study shows that the detergent method was more reliable compared to the PCI method.

\section{Conclusion}

Two extraction protocols were examined to study their effectiveness and efficiency in extracting a pure and high quantity of genomic DNA from blood samples. 
In conclusion, this study represents a reliable approach for genomic DNA isolation from frozen blood samples. The quality and quantity of genomic DNA varied while different commercial detergents were used, and the variation may be due to the presence of chemical components such as organic material, enzymes (e.g. proteases, lipases) and chelating complexes (e.g. EDTA).

Though it seems that Ariel and Tide detergents are better detergents to get purity and yield but there was no difference in downstream processing (PCR the heart of genomics) among all the detergents, suggesting that all detergents used in the present study can be recommended for DNA extraction and downstream applications such as PCR. This method is highly economical and more efficient rather than traditional protocols, because of the use of proteinase-K, RNaseA and guanidium hydrochloride are more cost-effective in the PCI method. Based on the results we reported a useful method to extract genomic DNA by using laundry detergents from long-term-frozen $\left(-20^{\circ} \mathrm{C}\right)$ whole blood samples that may be considered a reliable and potential resource for future molecular studies like PCR amplification, restriction enzyme digestion, and whole genome sequence through next-generation sequence technology. This method may be considered the best choice for samples that have to be subjected to desired gene amplification.

\section{Acknowledgments}

We kindly express our gratitude to the Director General, Indian Council of Agricultural Research (ICAR) and Director, National Dairy Research Institute (NDRI) Karnal, Dantiwada Agricultural University, Navsari Agricultural University Gujarat, "NICRA Project Grant No- 2049-3033" for providing financial assistance and necessary facilities to carry out this study.

\section{Conflict of interest}

The authors declare that there is no conflict of interest.

\section{References}

Al-Shuhaib, M.B.S.A. 2017. A universal, rapid, and inexpensive method for genomic DNA isolation from the whole blood of mammals and birds. J. Genet. 96(1), 171-176.

Bailes, S.M., Devers, J.J., Kirby, J.D. and Rhoads, D.D. 2007. An inexpensive, simple protocol for DNA isolation from blood for high-throughput genotyping by polymerase chain reaction or restriction endonuclease digestion. Poult. Sci. 86, 102-106.

Bakker, E. 2006. Is the DNA Sequence the Gold Standard in Genetic Testing Quality of Molecular Genetic Tests Assessed. Clin. Chem. 52, 557-558.

Chacon-Cortes, D., Haupt, L., Lea, R. and Griffiths, L. 2012. Comparison of genomic DNA extraction techniques from whole blood samples: a time, cost and quality evaluation study. Mol. Biol. Rep. 39, 5961-5966.

Chen, H., Rangasamy, M., Tan, S.Y., Wang, H. and Siegfried, B.D. 2010. Evaluation of Five Methods for Total DNA Extraction from Western Corn Rootworm Beetles. PLoS ONE 5(8), e11963. doi:10.1371/journal.pone.0011963.

Devi, S.G., Fathima, A.A., Radha, S., Arunraj, R., Curtis, W.R. and Ramya, M.A. 2015. Rapid and Economical Method for Efficient DNA Extraction from Diverse Soils Suitable for Metagenomic Applications. PLoS ONE 10(7), e0132441. Doi: 10.1371/journal. pone.0132441.

Di Pietro, F., Ortenzi, F., Tilio, M., Concetti, F. and Napolioni, V. 2011. Genomic DNA extraction from whole blood stored from 15 - to 30 -years at $-20^{\circ} \mathrm{C}$ by rapid phenol chloroform protocol: A useful tool for genetic epidemiology studies. Mol. Cell Probes 25(1), 44-48.

Ghaheri, M., Kahrizi, D., Yari, K., Babaie, A., Suthar, R.S. and Kazemi, E. 2016. A comparative evaluation of four DNA extraction protocols from whole blood sample. Cell Mol. Biol. 62(3), 120124.

Goldenberger, D., Perschil, I., Ritzler, M. and Altwegg, M. 1995. A simple "universal" DNA extraction procedure using SDS and proteinase $\mathrm{K}$ is compatible with direct PCR amplification. PCR Methods Appl. 4, 368-370.

Green, M.R. and Sambrook, J. 2012. Molecular Cloning: A Laboratory Manual, $4^{\text {th }}$ Ed. New York: Cold Spring Harbor Laboratory Press; (Vol. 1) pp: 2-80.

Griffin, J. 2013. Methods of sperm DNA extraction for genetic and epigenetic studies. Methods Mol. Biol. 927, 379-384.

Hackmann, T.J. and Spain, J.N. 2010. Invited review: ruminant ecology and evolution: perspectives useful to ruminant livestock research and production. J. Dairy Sci. 93, 1320-1334.

Hassani, A. and Khan, G. 2015. A simple procedure for the extraction of DNA from long-term formalinpreserved brain tissues for the detection of EBV by PCR. Exp. Mol. Pathol. 99, 558-563.

Huberman, J.A. 1995. Importance of measuring nucleic acid absorbance at $240 \mathrm{~nm}$ as well as at 260 and 280 nm. Biotechniques 18(4), 636.

Jiri, D. and Petrek, M. 2002. A Sugar, Laundry Detergent, and Salt Method for Isolation of Deoxyribonucleic Acid from Blood. Biomed. Papers 146(2), 37-39.

Joshi, C.G., Rank, D.N., Brahmkshtrl, B.P., Patel, A.V., Vataliya, P.H. and Solanki, J.V. 1998. Comparison of DNA Extraction Protocols on Frozen Stored Blood Samples. Indian Vet. J. 75, 1038-1039. 
Koshy, L., Anju, A.L., Harikrishnan, S., Kutty, V.R, Jissa, V.T., Kurikesu, I., Jayachandran, P., Jayakumaran Nair, A., Ganga Prasad, A., Nair, G.M. and Sudhakaran, P.R. 2016. Evaluating genomic DNA extraction methods from whole blood using end point and real-time-PCR assays. Mol. Biol. Rep. 44(1), 97-108.

Kumar, O.S., Sharma, M.K. and Singh, D. 2006. DNA Isolation from goat blood using different brands of detergents and its downstream applications. Indian J. Exp. Biol. 44, 852-854.

Liu, Y.F., Gao, J.L., Yang, Y.F., Ku, T. and Zan, L.S. 2014. Novel extraction method of genomic DNA suitable for long-fragment amplification from small amounts of milk. J. Dairy Sci. 97, 1-6.

Lundblom, K., Macharia, A., Lebbad, M., Mohammed, A. and Färnert, A. 2011. High-speed shaking of frozen blood clots for isolation of human and malaria parasite DNA. Malar. J. 10, 229. Doi: 10.1186/1475-2875-10-229.

Murphy, M.A., Shariflou, M.R. and Moran, C. 2002. High quality genomic DNA extraction from large milk samples. J. Dairy Res. 69, 645-649.

Murray, J.M., Watson, A.T. and Carr, A.M. 2016. Extraction of chromosomal DNA from Schizosaccharomyces pombe. Cold Spring Harb. Protoc. 5. doi: 10.1101/pdb.prot090985.

Nasiri, H., Forouzandeh, M. and Rahbarizadesh, F. 2005. Modified salting out methods: High Yield Quality Genomic DNA Isolation from Whole Blood Using Laundry Detergent. J. Clin. Lab. Anal. 19(6), 229-232.

Neary, M.T., Neary, J.M., Lund, G.K., Garry, F.B., Holt, T.N., Mohun, T.J. and Breckenridge, R.A.
2014. A comparison of DNA collection methods in cattle and yaks. J. Anim. Sci. 92, 3811-3815.

Permenter, J., Ishwar, A., Rounsavall, A., Smith, M. Faske, J., Sailey, C.J. and Alfaro, M,P. 2015. Quantitative Analysis of Genomic DNA Degradation in Whole Blood under Various Storage Conditions for Molecular Diagnostic Testing. Mol. Cell Probes 29(6), 449-453.

Psifidi, A., Dovas, C.I., Bramis, G., Lazou, T., Russel, C.L., Arsenos, G. and Banos, G. 2015. Comparison of eleven methods for genomic DNA extraction suitable for large-scale whole-genome genotyping and long-term DNA banking using blood samples. PLoS One 10. doi: 10.1371/journal.pone.0115960.

Psifidi, A., Dovas, C.I. and Banos, G. 2010. A comparison of six methods for genomic DNA isolation suitable for PCR-based genotyping applications using ovine milk samples. Mol. Cell Probes 24, 93-98.

Qamar, W., Rashid Khan, M. and Arafah, A. 2017. Optimization of conditions to extract high quality DNA for PCR analysis from whole blood using SDS-proteinase K method. Saudi J. Biol. Sci. 24, 1465-1469.

Seeker, L.A., Holland, R., Underwood, S., Fairlie, J., Psifidi, A., Ilska, J.J., Bagnall, A., Whitelaw, B., Banos, G. and Nussey, D.H. 2016. Method Specific Calibration Corrects for DNA Extraction Method Effects on Relative Telomere Length Measurements by Quantitative PCR. PLoS ONE 11(10). Doi: 10.1371/journal. pone.016404.

Suenaga, E. and Nakamura, H. 2005. Evaluation of three methods for effective extraction of DNA from human hair. J. Chrom. B. 820(1), 137-141. 